\title{
SPATIAL VARIABILITY OF SOIL PHYSICAL PROPERTIES IN TWO MANAGEMENT SYSTEMS IN SUGARCANE CROP
}

\section{LAÉRCIO A. DE CARVALHO ${ }^{1}$, ISMAEL MEURER ${ }^{2}$, CARLOS A. DA SILVA JUNIOR ${ }^{3}$, JOSÉ F. CENTURION ${ }^{4}$}

\begin{abstract}
The aim of this study was to characterize the spatial variability of soil bulk density $(\mathrm{Bd})$, soil moisture content $(\theta)$ and total porosity (Tp) in two management systems of sugarcane harvesting, with or without burning, in a Haplustox soil, in the $0-0.20 \mathrm{~m}$ layer. The study area is located in Rio Brilhante, state of Mato Grosso do Sul, Brazil, in Eldorado Sugar Mill. The plots have presented $180 \mathrm{~m}$ length, and $145.6 \mathrm{~m}$ width, totaling 90 points distributed in the form of a grid of nine rows by ten columns, with points spaced $20 \mathrm{~m}$ from its neighbor. Soil samples were collected at 0-0.20 m layer in 2007/2008 and 2008/2009 crops. The harvest with burning system had a higher density compared to mechanized harvest, in the two study periods. The moisture content as well as the porosity increased proportionally with the decrease of the density of the harvest burning system compared to the mechanized.
\end{abstract}

KEYWORDS: mechanized harvesting, bulk density, Saccharum spp.

\section{VARIABILIDADE ESPACIAL DAS PROPRIEDADES FÍSICAS DO SOLO EM DOIS SISTEMAS DE MANEJO NA COLHEITA DA CANA-DE-AÇÚCAR}

RESUMO: O objetivo deste trabalho foi caracterizar a variabilidade espacial da densidade do solo (Ds), teor de água no solo $(\theta)$ e porosidade total $(\mathrm{Pt})$ em dois sistemas de manejo da colheita da cana-de-açúcar, com queima e sem queima, em um Latossolo Vermelho, na camada de 0-0,20 m. A área de estudo está localizada no município de Rio Brilhante-MS, na Usina Eldorado. A parcela de cada talhão apresentou malha com comprimento de $180 \mathrm{~m}$ e largura de $145,6 \mathrm{~m}$, perfazendo 90 pontos distribuídos na forma de uma grade de nove colunas por dez linhas, com pontos distanciados $20 \mathrm{~m}$ de seu vizinho. Foram coletadas amostras de solo na camada de 0-0,20 m, nos anos agrícolas de 2007/2008 e 2008/2009. O sistema de colheita com queima apresentou maior densidade em relação ao mecanizado, nos dois períodos de análise. O teor de água no solo, assim como a porosidade, teve aumento proporcional com relação à diminuição da densidade do sistema de colheita com queima para com o mecanizado.

PALAVRAS-CHAVE: colheita mecanizada, densidade do solo, Saccharum spp.

\section{INTRODUCTION}

For the plant to be able to fully deploy its roots in the soil profile for water and nutrients, it is necessary that it presents a good condition of physical and chemical structure, allowing changes due to management applied, thus aiming higher productivity (FREDDI et. al., 2006).

With the use of machines and implements of greater weight in the cultivation and management of sugarcane, it becomes necessary the development of researches that attempt to determine the impact of these practices in their physical and hybrid attributes (SOUZA et. al., 2006a).

\footnotetext{
${ }^{1}$ Eng ${ }^{\underline{0}}$ Agrônomo, Doutor, Professor Adjunto, Universidade Estadual de Mato Grosso do Sul, Dourados - MS, Brasil, lcarvalh@uems.br.

${ }^{2}$ Discente em Agronomia, bolsista de IC/Fundect, Universidade Estadual de Mato Grosso do Sul (UEMS), Aquidauana - MS, Brasil.

${ }^{3}$ Discente em Agronomia, Universidade Estadual de Mato Grosso do Sul (UEMS), Aquidauana - MS, Brasil.

${ }^{4}$ Professor Adjunto, Departamento de Solos e Adubos, Faculdade de Ciências Agrárias e Veterinárias, Universidade Estadual Paulista "Júlio de Mesquita Filho" (UNESP), Jaboticabal - SP, Brasil.

Recebido pelo Conselho Editorial em: 5-5-2010

Aprovado pelo Conselho Editorial em: 5-9-2011
} 
For determination of soil physical quality, different properties are analyzed related to the shape and structural stability, such as density, porosity, moisture content and soil resistance to root penetration (SILVA et. al., 2005).

Soil compaction refers to the increase of density as a result of reducing its volume. This results in the expulsion of air from the pores and therefore a particle rearrangement, reducing porosity and increasing the density (RALISCH et. al., 2008).

Because of that, the recent trend of adopting farming practices that lead to greater sustainability of the system persuades sugarcane agro-industry to review its processes, including harvesting cane without previous burning or without straw removal by burning, called a raw cane, or green cane.

According to VITTI et al. (2008), the residues of sugarcane left by mechanical harvest represents around $15 \mathrm{t} \mathrm{ha}^{-1}$ of dry matter on the soil, 20 to $80 \mathrm{~kg} \mathrm{ha}^{-1}$ of nitrogen, and half of that value in the form of sulfur, forming a layer of $8-10 \mathrm{~cm}$ thick.

According to JOHNSON \& RICHARD (2005), the economic importance in the culture of sugarcane justifies studies of spatial variability of soil attributes. Using these techniques, there is greater understanding of variations in the crop, thereby determining whether or not an attribute displays the spatial structure and, once known the model of spatial dependence, it is possible to map the studied area, providing a better management decision.

The objective of this study was to characterize the spatial variability of soil physical properties in two management systems in sugarcane harvest, raw and burning, on a Dystrophic Haplustox at a depth of $0-0.20 \mathrm{~m}$.

\section{MATERIAL AND METHODS}

The area of the study is located in the municipality of Rio Brilhante, in the State of Mato Grosso do Sul, Brazil, at Eldorado Sugar Mill (Usina Eldorado-ETH Bioenergia S/A), located in geographical coordinates, latitude $21^{\circ} 50^{\prime} \mathrm{S}$ and longitude $53^{\circ} 57^{\prime} \mathrm{W}$ at an elevation of $312 \mathrm{~m}$. The climate was characterized as tropical Aw, according to Köppen-Geiger, with average rainfall of $120 \mathrm{~mm}$ per month.

The experiment was conducted in two plots of sugarcane representing the same class of soil, classified as Dystrophic Haplustox, with $501 \mathrm{~g} \mathrm{~kg}^{-1}$ of clay, $420 \mathrm{~g} \mathrm{~kg}^{-1}$ of silt, and $79 \mathrm{~g} \mathrm{~kg}^{-1}$ of sand, according to the methodology of EMBRAPA (2006).

The experimental parcel of each plot was $180 \mathrm{~m}$ long and $145.6 \mathrm{~m}$ wide, totaling 90 points where soil samples were collected at a depth of 0-0.20 m for analysis of physical attributes.

The distribution of sampling points in the mesh was made in a grid form, of nine rows by ten columns, with a point distant from its neighbor at regular intervals of $20 \mathrm{~m}$. Soil samples were collected in two periods, 2007/2008 and 2008/2009, just after the second and third sugarcane cutting, respectively.

In the pre-established period, a sample was removed of each point in the depth of $0-0.20 \mathrm{~m}$, totaling 360 samples in the two plots and periods. Soil samples were collected using the volumetric rings of deformed structure with a volume already known, with samplers (Type Uhland).

The wet sample mass was measured and it was then dried at a temperature of $105{ }^{\circ} \mathrm{C}$, until reaching constant mass for determination of bulk density $(\mathrm{Bd})$, water content $(\theta)$ and porosity $(\mathrm{Tp})$.

Initially, it was applied the procedures of descriptive statistical analysis with the help of the program STATISTICA 4.3 to visualize the general behavior of the data. The attributes that showed discrepant values ("outliers") were discarded and, in these situations, it was applied again the exploratory analysis. 
For analysis of normality, was applied the parametric test of Shapiro \& Wilk, where the study of percentage points was based on the table presented by REES (1995), and non-parametric of normality of Kolmogorov-Smirnov (KS), obtained in the same program.

Through data analysis, it could verify and describe their mathematical and statistical measures, which improves the efficiency of the analysis and helps in the decision of the hypothesis of stationarity which may be assumed (FOLEGATTI, 1996).

Later, geostatistical techniques were applied in the study of spatial variability, with the construction of semivariograms to analyze the degree of spatial dependence among the 90 points of each plot, in each period, in the studied layer, using the application GS + (version 7.0).

\section{RESULTS AND DISCUSSION}

Tables 1, 2 and 3 show the values obtained for the descriptive statistical measures of the variables density, water content and porosity, respectively, for the layer of 0-0.20 $\mathrm{m}$ of soil in both systems of sugarcane harvest, in each period.

TABLE 1. Summary statistics for the variable bulk density.

\begin{tabular}{|c|c|c|c|c|}
\hline \multirow{3}{*}{ Statistical Measures } & \multicolumn{4}{|c|}{ Density (Bs) } \\
\hline & \multicolumn{2}{|c|}{$2007 / 2008$} & \multicolumn{2}{|c|}{$2008 / 2009$} \\
\hline & Burning & Mechanized & Burning & Mechanized \\
\hline & - n & ---------- & & --------. \\
\hline Mean & 1.55 & 1.27 & 1.57 & 1.47 \\
\hline Median & 1.56 & 1.30 & 1.58 & 1.47 \\
\hline Maximum & 1.73 & 1.54 & 1.82 & 1.72 \\
\hline Minimum & 1.33 & 0.87 & 1.17 & 1.17 \\
\hline Upper quartile & 1.60 & 1.41 & 1.66 & 1.58 \\
\hline Lower quartile & 1.50 & 1.12 & 1.49 & 1.37 \\
\hline $\begin{array}{l}\text { Standard } \\
\text { deviation }\end{array}$ & 0.08 & 0.17 & 0.13 & 0.13 \\
\hline Coeff. Var. (\%) & 5.03 & 12.35 & 8.14 & 8.64 \\
\hline Kurtosis & 0.20 & -0.84 & 0.78 & -0.90 \\
\hline Asymmetry & -0.52 & -0.43 & -0.64 & 0.01 \\
\hline
\end{tabular}

TABLE 2. Summary statistics for the variable moisture content.

\begin{tabular}{|c|c|c|c|c|}
\hline \multirow{3}{*}{ Statistical Measures } & \multicolumn{4}{|c|}{ Moisture Content $(\theta)$} \\
\hline & \multicolumn{2}{|c|}{$2007 / 2008$} & \multicolumn{2}{|c|}{ 2008/2009 } \\
\hline & Burning & Mechanized & Burning & Mechanized \\
\hline Mean & ר & 24,41 & 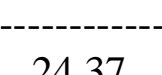 & 6 \\
\hline Median & 22.47 & $\begin{array}{l}24.41 \\
24.41\end{array}$ & 25.36 & $\begin{array}{l}21.00 \\
26.62\end{array}$ \\
\hline Maximum & 30.97 & 43.48 & 40.78 & 43.16 \\
\hline Minimum & 16.67 & 7.76 & 9.59 & 19.26 \\
\hline Upper quartile & 23.56 & 27.48 & 29.07 & 29.05 \\
\hline Lower quartile & 20.75 & 21.25 & 18.62 & 24.82 \\
\hline $\begin{array}{l}\text { Standard } \\
\text { deviation }\end{array}$ & 2.37 & 4.84 & 6.91 & 3.51 \\
\hline Coeff. Var. (\%) & 10.57 & 18.55 & 25.03 & 13.66 \\
\hline Kurtosis & 1.85 & 3.22 & -0.60 & 4.77 \\
\hline Asymmetry & 0.41 & -0.05 & -0.03 & 1.36 \\
\hline
\end{tabular}


TABLE 3. Summary statistics for the variable total porosity.

\begin{tabular}{lcccc}
\hline \multirow{2}{*}{ Statistical Measures } & \multicolumn{4}{c}{ Total Porosity (Tp) } \\
\cline { 2 - 5 } & \multicolumn{2}{c}{ 2007/2008 } & \multicolumn{2}{c}{ 2008/2009 } \\
\cline { 2 - 5 } Mean & --------16 & Mechanized & Burning & Mechanized \\
Median & 46.16 & 55.99 & 45.43 & 48.96 \\
Maximum & 45.78 & 54.94 & 45.29 & 49.11 \\
Minimum & 53.75 & 69.65 & 59.31 & 59.36 \\
Upper quartile & 39.87 & 46.47 & 36.97 & 40.40 \\
Lower quartile & 47.63 & 60.77 & 47.93 & 52.09 \\
Standard & 44.25 & 50.81 & 42.18 & 45.13 \\
deviation & 2.72 & 5.85 & 4.48 & 4.42 \\
Coeff. Var. (\%) & 5.91 & 10.44 & 9.89 & 8.87 \\
Kurtosis & 0.20 & -0.84 & 0.78 & -0.90 \\
Asymmetry & 0.52 & 0.43 & 0.64 & 0.01 \\
\hline
\end{tabular}

In relation to the mean and median values, it is observed that in all the variables and the two harvesting systems, the ratio mean/median is close to 1 , showing symmetric distributions, which may also be confirmed by asymmetry values near zero.

Corroborating these results, CORÁ \& BERALDO (2006) studied the spatial variability of soil properties in Haplustox soil with sugarcane, and they observed that the values of the mean and median for all variables were similar.

According to CAMBARDELLA et al. (1994), this may be an indication that the measures of central tendency are not dominated by outliers in the distribution.

Usually, measures of central tendency are insufficient to fully describe a set of data, so it was necessary to use measures of dispersion to enrich this description.

According to ORTIZ (2003), for a normal distribution, the kurtosis coefficients must be zero, and the values between +2 and -2 are accepted. It is noted in Table 1 and Table 3 that the kurtosis coefficients of the variable $\mathrm{Tp}$ and Bs are close to zero, indicating symmetric distributions. On the contrary, it is observed in Table 2 that for the variable $\theta$, these values were more distant from zero, thus indicating asymmetric distributions.

For variable moisture content (Table 2), even with relatively high values of kurtosis in mechanized harvesting, it may be verified that, in the management with previous burning, the values are within the acceptable range. According to SOUZA (1999), where it is indicated a marked asymmetry to the right or left, there may be a high frequency of values below or above mean, respectively.

The variability of the soil properties (Table 1,2 and 3) measured by the coefficient of variation may be considered as the first indication of heterogeneity in the data.

In this case, according to the classification of WARRICK \& NIELSEN (1980), results showed low magnitude of variation $(<12 \%)$ for the variables $\mathrm{Bs}$ and $\mathrm{Tp}$, in agreement with the results of SOUZA et al. (2006a) and RAMIREZ-LOPEZ et al. (2008), in the same soil type.

The data also show mean C.V. (12-24\%) for the variable $\theta$, disagreeing with SOUZA et al. (2006b), who obtained low C.V. for this variable in intensive cultivation with sugarcane.

The maximum values for all variables and the two harvesting systems (Table 1, 2 and 3) are outside the range given by the upper quartile. According to CARVALHO (2006), this suggests that the data are possible candidates for asymmetric values. 
Thus, in Tables 1, 2 and 3 it is confirmed that the mechanized system obtained values lower in density, with increasing porosity, and, consequently, the moisture content of the soil. SOUZA et al. (2005) comparing the harvest system on sugarcane also found better structural conditions of the soil with straw management system, assuming that was due to the addition of about $12 \mathrm{t} \mathrm{ha}^{-1}$ of plant material as straw.

Even with the low coefficient of variation obtained in most variables, the graphs of semivariograms (Figure 1) showed no spatial dependence in much of the management with burning, in the first analyzed period.
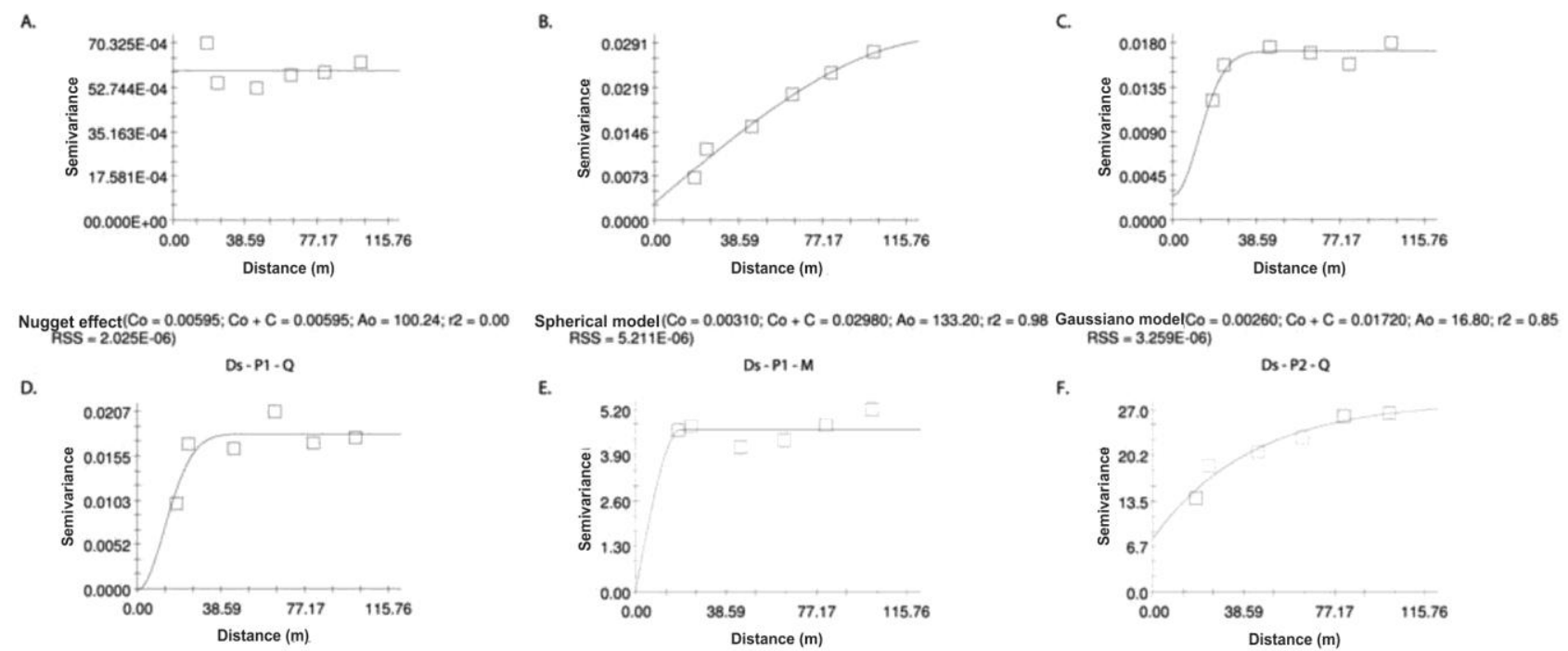

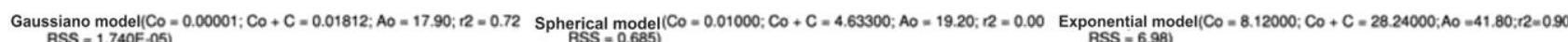
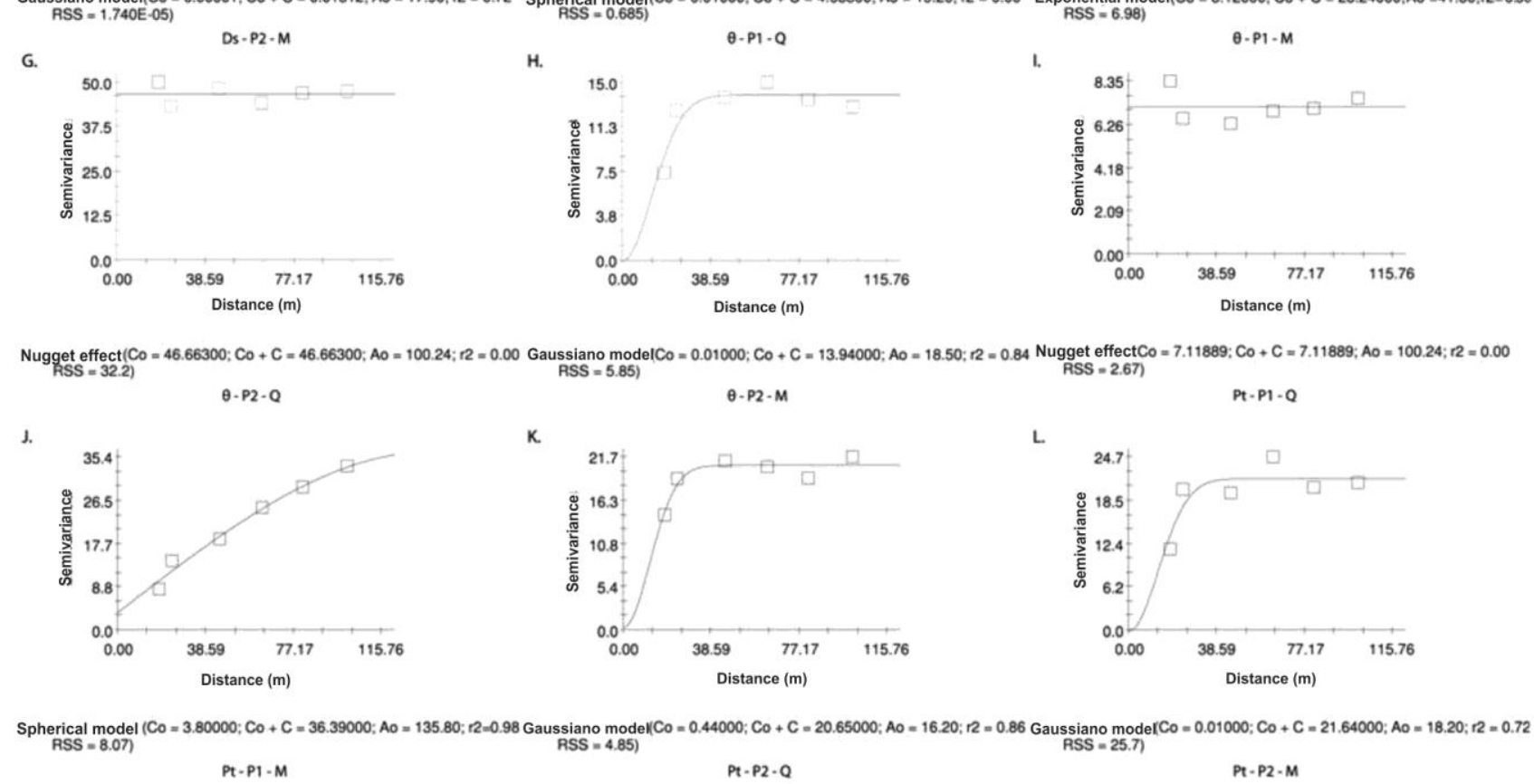

FIGURE 1. Experimental semivariogram is modeled for the variable bulk density: (A) with burning, (B) mechanized in 2008, (C) with burning and (D) mechanized in 2009. Total porosity: (E) with burning, (F) mechanized in 2008, (G) with burning and (H) mechanized in 2009. Soil moisture content (I) with burning, (J) mechanized in 2008, (K) with burning and (L) mechanized in 2009.

According to CAMPOS et al. (2008), the reach indicates the limit of the spatial dependency of the variable, i.e., measurements performed at distances greater than the extent has a random spatial distribution, and therefore is independent of each other. Moreover, measurements performed at 
distances smaller than the range are correlated with each other, which allow us to make interpolations for spacing smaller than the sampled.

Looking at the graphs that showed pure nugget effect in Figure 1 (graphs A, G and I), it may observe that its range does not indicate any correlation between sampling points in the distance of $20 \mathrm{~m}$, but it does when it is more than 100 meters, showing the full spatial independence, confirmed by the coefficient of determination $\left(\mathrm{r}^{2}\right)$ of less than $5 \%$. Although the graphs B, F and J present range ranging from 41.80 to $135.80 \mathrm{~m}$, the coefficient $\mathrm{r}^{2}(>5 \%)$ indicates a correlation between neighboring points, despite the trend line of the graphics.

In general, the other graphs presented range around $16.8 \mathrm{~m}$ to $17.9 \mathrm{~m}$ for the variable density, 18.5 to $19.2 \mathrm{~m}$ for the variable moisture content, and 16.2 to $18.2 \mathrm{~m}$ for the variable total porosity, with coefficient $\mathrm{r}^{2}$ greater than $5 \%$. In order to analyze the degree of spatial dependence of the physical attributes under study, we used the classification of CAMBARDELLA et al. (1994), where it is calculated the ratio $\mathrm{Co} /(\mathrm{Co}+\mathrm{C})$. Thus, it is considered strong spatial dependence in semivariograms which have a nugget effect of $75 \%$ of the baseline, moderate when it is between 25 and $75 \%$, or low if the ratio is less than $25 \%$.

The analysis of the relation $\mathrm{Co} /(\mathrm{Co}+\mathrm{C})$ showed that all variables have low degree of spatial dependence, contrary to the claims of SOUZA et al. (2010), except for the variable moisture in the mechanized management (second period) which had moderate spatial dependence.

The model of the semivariogram, mostly, was fitter for the Gaussian model, in disagreement with SIQUEIRA (2006), which obtained the highest setting in the spherical model. To check the normality of data distribution, tests of Shapiro-Wilk and Kolmogorov-Smirnov (KS) were applied, which can be viewed in graphical histograms (Figure 2).
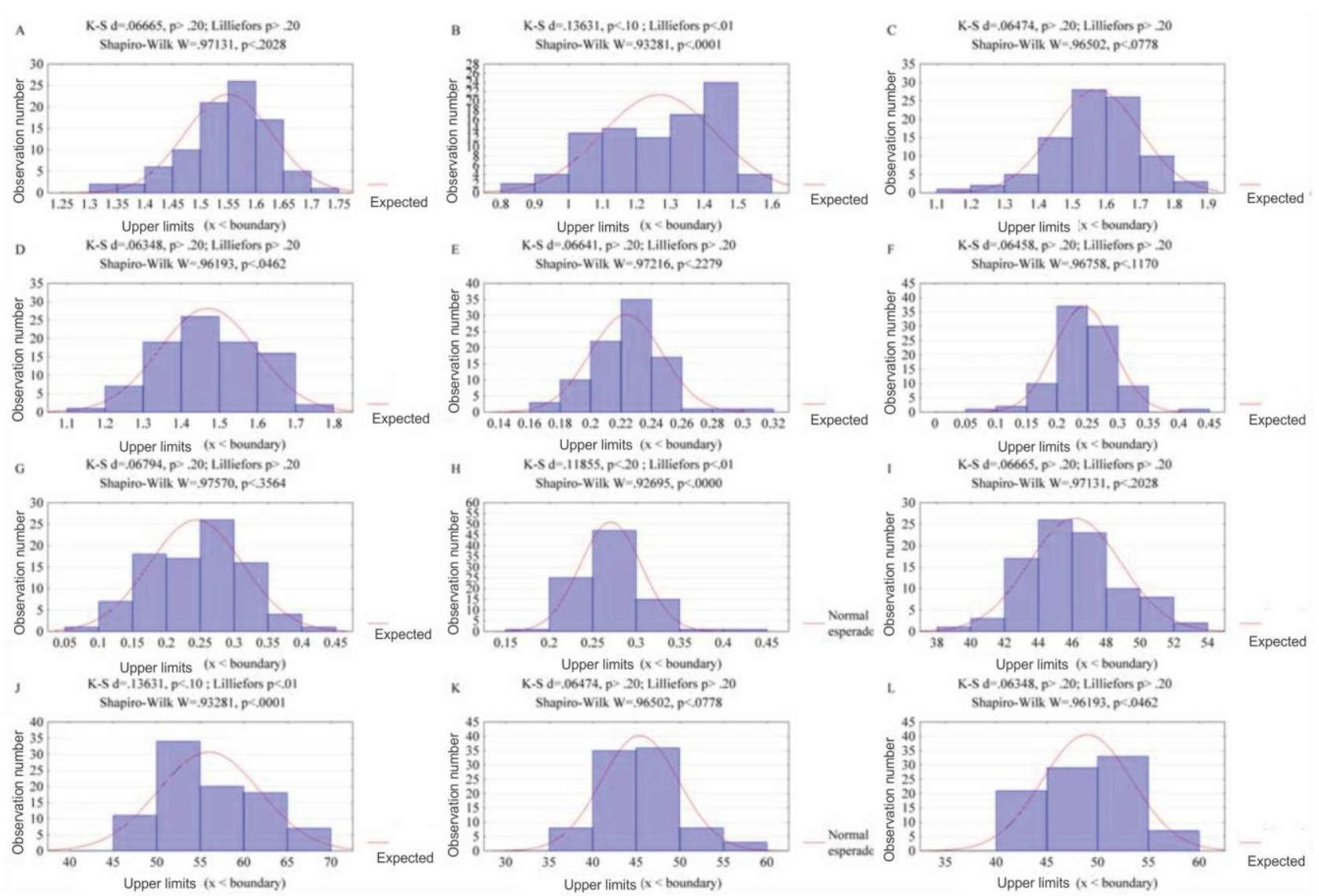

FIGURE 2. Histograms and normality tests for the variable bulk density (A) mechanized, (B) with burning in 2008, (C) mechanized and (D) with burning in 2009; total porosity (E) mechanized, (F) with burning in 2008, (G) mechanized and (H) with burning in 2009; soil moisture content (I) mechanized, (J) with burning in 2008 , (K) mechanized and (L) with burning in 2009. 
The Kolmogorov-Smirnov (KS) test indicated normality for all variables, since $\mathrm{p}>5 \%$ probability. SOUZA et al. (2010) also found normal values for this parameter by analyzing the Bs in Dystrophic Haplustox with sugarcane.

It may be noted that in Figure 2, the parametric test of Shapiro \& Wilk indicated normality in the graphs A, C, E, F, G, I and K, since p>5\%. Similar results were obtained by MELO FILHO \& LIBARDI (2005), confirming normal distribution for the variable moisture content and LIMA et al. (2009) who, analyzing the physical attributes of soil under pasture and secondary vegetation, found normal distribution for the variable density and moisture content.

In the other graphs $(\mathrm{B}, \mathrm{D}, \mathrm{H}, \mathrm{J}, \mathrm{L})$, the test did not achieve normality and correlated with semivariograms that showed a strong trend in the data.

\section{CONCLUSIONS}

The geostatistical methods used were adequate to describe the spatial dependence structure of variables: density, porosity and soil moisture content;

The presence of highest rates in the variable density, comparing the two periods of analysis and management methods, shows that the succession of cycles and time of cultivation of the crop have led to greater increases in density in the mechanized harvesting;

The harvesting system with burning had higher soil bulk density compared to mechanized harvesting system, in two different periods of analysis, which may be suffering from compression;

The soil moisture content and the porosity was clearly increased in proportion with respect to the decrease in density of the harvesting system with burning by the mechanized system, showing the existence of correlation;

The variables studied showed weak spatial dependence structure, especially in the first period of analysis and harvesting management with previous burning of straw.

\section{REFERENCES}

CAMBARDELLA, C. A.; MOORMAN, T. B.; NOVAK, J. M.; PARKIN, T. B.; KARLEN, D. L.; TURCO, R. F.; KONOPKA, A. E. Fieldscale variability of soil properties in Central Iowa soils. Soil Science Society of America Journal, Madison, v.58, p.1501-1511, 1994.

CAMPOS, M. C. C.; MARQUES JÚNIOR, J.; PEREIRA, G. T.; SOUZA, Z. M.; BARBIERI, D.M. Aplicação de adubo e corretivo após o corte da cana-planta utilizando técnicas geoestatísticas.

Ciência Rural, Santa Maria, v.38, n.4, p.974-980, 2008.

CARVALHO, L. A. Distribuição espacial dos parâmetros da equação da condutividade hidráulica em função da umidade do solo. 2006. 180 f. Doutorado (Tese) - Escola Superior de Agricultura "Luiz de Queiroz", Universidade de São Paulo, Piracicaba, 2006.

CORÁ, J. E.; BERALDO, J. M. Variabilidade espacial de atributos do solo antes e após calagem e fosfatagem em doses variadas na cultura de cana-de-açúcar. Engenharia Agrícola, Jaboticabal, v.26, n.2, p.374-387, 2006.

EMBRAPA. EMPRESA BRASILEIRA DE PESQUISA AGROPECUÁRIA. Centro Nacional de Pesquisa de Solos. Sistema brasileiro de classificação de solos. Brasília: EMBRAPA Produção de Informação, 2006. 412 p.

FOLEGATTI, M. V. Estabilidade temporal e variabilidade espacial da teor de água e do armazenamento de água em solo siltoso. 1996. 84 f. Tese (Livre Docência) - Escola Superior de Agricultura "Luiz de Queiroz", Universidade de são Paulo, Piracicaba, 1996. 
FREDDI, O. S.; CARVALHO, M. P.; VERONESI JÚNIOR, V.; CARVALHO, G. J.

Produtividade do milho relacionada com a resistência mecânica à penetração do solo sob preparo convencional. Engenharia Agrícola, Jaboticabal, v.26, n.1, p.113-121, 2006.

JOHNSON, R. M.; RICHARD, E. P. Sugarcane yield, sugarcane quality, and soil variability in Louisiana. Agronomy Journal, Madison, v.97, n.3, p.760-771, 2005. Disponivel em:

< http://agron.scijournals.org/cgi/reprint/97/3/760>. Acesso em: 17 mar. 2010.

LIMA, J. S. S.; SATTLER, M. A.; PASSOS, R. R.; OLIVEIRA, P. C.; SOUZA, G. S. Variabilidade espacial de atributos físicos de um argissolo vermelho-amarelo sob pastagem e vegetação secundária em regeneração natural. Engenharia Agrícola, Jaboticabal, v.29, n.2, p.185195, 2009.

MELO FILHO, J.; LIBARDI, P. L. Estabilidade temporal de medidas do teor e do potencial mátrico da água no solo em uma transeção. Revista Brasileira de Ciência do Solo, Viçosa-MG, v.29, n.4, p.497-506, 2005.

ORTIZ, J. L. Emprego do geoprocessamento no estudo da relação entre potencial produtivo de um povoamento de eucalipto e atributos do solo e do relevo. 2003. 205 f. Dissertação (Mestrado) Escola Superior de Agricultura "Luiz de Queiroz", Universidade de São Paulo, Piracicaba, 2003.

RALISCH, R.; MIRANDA, T. M.; OKUMURA, R. S.; BARBOSA, G. M. de C.; GUIMARÃES, M. de F.; SCOPEL, E; BALBINO, L. C. Resistência à penetração de um Latossolo Vermelho Amarelo do Cerrado sob diferentes sistemas de manejo. Revista Brasileira de Engenharia Agrícola e Ambiental, Campina Grande, v.12, n.4, p.381-384, 2008.

RAMIREZ-LÓPEZ, L.; SÁNCHEZ, A. R.; TAMAYO, J. H. C. Variabilidad espacial de atributos físicos de un typic haplustox de los llanos orientales de Colômbia. Engenharia Agrícola, Jaboticabal, v.28, n.1, p.55-63, 2008.

REES, D.G. Essential statistics. $3^{\text {rd }}$ ed. London: Chapmam and Hall, 1995. 265 p.

SILVA, R. R.; SILVA, M. L. N.; FERREIRA, M. M. Atributos físicos indicadores da qualidade do solo sob sistemas de manejo na Bacia Alto do Rio Grande-MG. Ciência e Agrotecnologia, Lavras, v.29, n. 4, p.719-730, 2005.

SIQUEIRA, G. M. Variabilidade de atributos físicos do solo determinados por métodos diversos. 2006. 163 f. Dissertação (Mestrado) - Universidade Estadual de Campinas, 2006.

SOUZA, L. C. de. Variabilidade espacial da salinidade de um solo aluvial no semi-árido paraibano. 1997. 77 f. Dissertação (Mestrado) - Universidade Federal de Paraíba, Campina Grande, 1999.

SOUZA, Z. M.; CAMPOS, M. C. C.; CAVALCANTE, Í. H. L.; MARQUES JÚNIOR, J.; CESARIN, L. G.; SOUZA, S. R. Dependência espacial da resistência do solo à penetração e teor de água do solo sob cultivo de cana-de-açúcar. Ciência Rural, Santa Maria, v.36, n.1, p.128-134, $2006 a$.

SOUZA, Z. M.; MARQUES JÚNIOR, J.; PEREIRA, G. T.; MONTANARI, R.; CAMPOS, M. C. C. Amostragem de solo para determinação de atributos químicos e físicos em área com variação nas formas do relevo. Revista Científica, Jaboticabal, v.34, n.2, p.249-256, 2006 b.

SOUZA, Z. M.; MARQUES JÚNIOR, J.; PEREIRA, G. T. Geoestatística e atributos do solo em áreas cultivadas com cana-de-açúcar. Ciência Rural, Santa Maria, v.40, n.1, p.48-56, 2010.

SOUZA, Z. M.; PRADO, R. M.; PAIXÃO, A. C. S.; CESARIN, L. G. Sistemas de colheita e manejo da palhada de cana-de-açúcar. Pesquisa Agropecuária Brasileira, Brasília, v.4, n.2, p.249256, 2005.

VITTI, A. C.; TRIVELIN, P. O.; CANTARELlA, H.; FRANCO, H. C. J.; FARONI, C. E.; OTTO, R.; TRIVELIN, M. O.; TOVAJAR.; J. G. Mineralização da palhada e crescimento de raízes de 
cana-de-açúcar relacionados com a adubação nitrogenada de plantio. Revista Brasileira de Ciência do Solo, Viçosa, v.32, p. 2757-2762, 2008.

WARRICK, A. W.; NIELSEN, D. R. Spatial variability of physical properties in the field. In: HILLEL,D. Applications of soil physics. New York: Academic Press, 1980. p.319-344. 